\title{
Survey of existing and emerging power conversion technologies relevant to a self- powered furnace
}

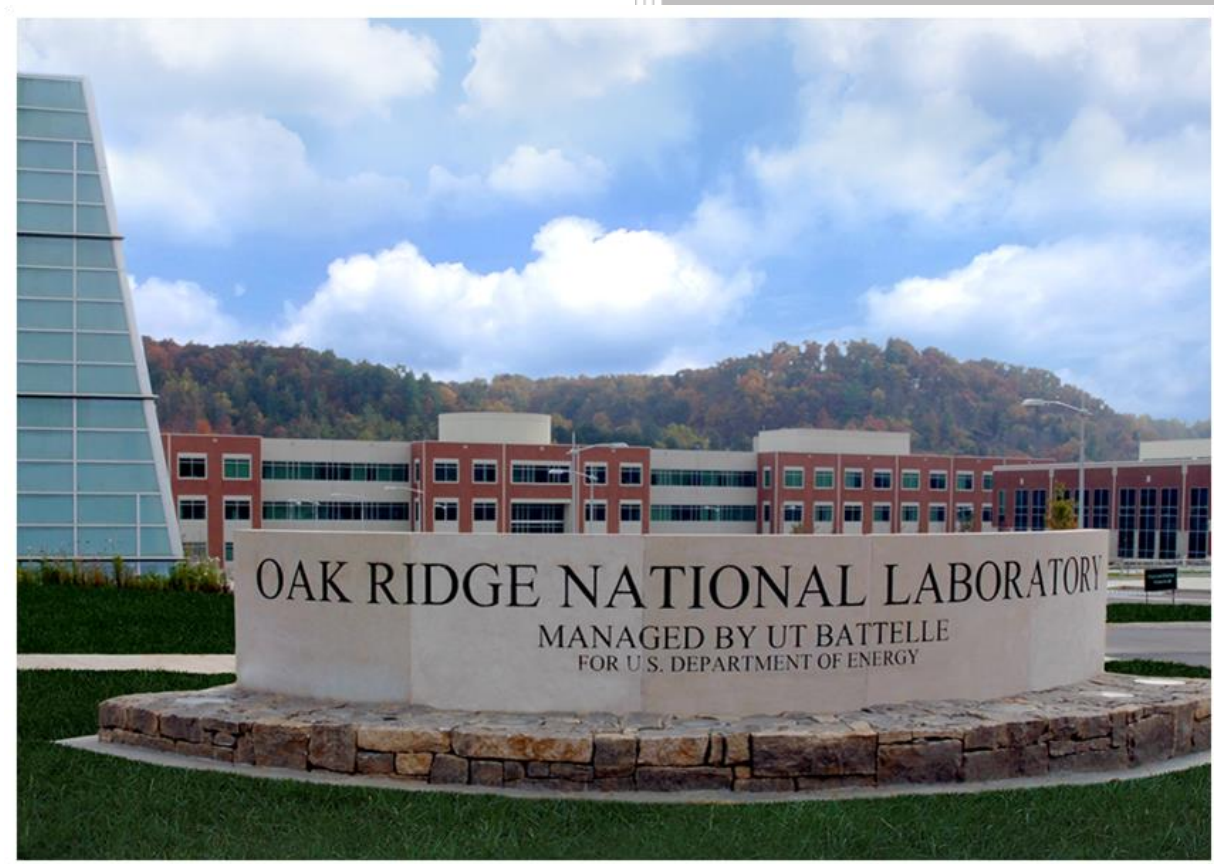

Approved for public release. Distribution is unlimited.
Kyle Gluesenkamp Ahmad Abu-Heiba John Thomas Mini Malhotra Philip Boudreaux Jeff Munk

January 2018 


\title{
DOCUMENT AVAILABILITY
}

Reports produced after January 1, 1996, are generally available free via US Department of Energy (DOE) SciTech Connect.

Website http://www.osti.gov/scitech/

Reports produced before January 1, 1996, may be purchased by members of the public from the following source:

\author{
National Technical Information Service \\ 5285 Port Royal Road \\ Springfield, VA 22161 \\ Telephone 703-605-6000 (1-800-553-6847) \\ TDD 703-487-4639 \\ Fax 703-605-6900 \\ E-mail info@ntis.gov \\ Website http://classic.ntis.gov/
}

Reports are available to DOE employees, DOE contractors, Energy Technology Data Exchange representatives, and International Nuclear Information System representatives from the following source:

Office of Scientific and Technical Information

PO Box 62

Oak Ridge, TN 37831

Telephone 865-576-8401

Fax 865-576-5728

E-mail reports@osti.gov

Website http://www.osti.gov/contact.html

This report was prepared as an account of work sponsored by an agency of the United States Government. Neither the United States Government nor any agency thereof, nor any of their employees, makes any warranty, express or implied, or assumes any legal liability or responsibility for the accuracy, completeness, or usefulness of any information, apparatus, product, or process disclosed, or represents that its use would not infringe privately owned rights. Reference herein to any specific commercial product, process, or service by trade name, trademark, manufacturer, or otherwise, does not necessarily constitute or imply its endorsement, recommendation, or favoring by the United States Government or any agency thereof. The views and opinions of authors expressed herein do not necessarily state or reflect those of the United States Government or any agency thereof. 
Energy and Transportation Science Division

\title{
Survey of existing and emerging power conversion technologies relevant to a self-powered furnace
}

\author{
Kyle Gluesenkamp \\ Ahmad Abu-Heiba \\ John Thomas \\ Mini Malhotra \\ Philip Boudreaux \\ Jeff Munk
}

Date Published:

January 2018

Prepared by

OAK RIDGE NATIONAL LABORATORY

Oak Ridge, TN 37831-6283

managed by

UT-BATTELLE, LLC

for the

US DEPARTMENT OF ENERGY

under contract DE-AC05-00OR22725 



\section{CONTENTS}

\section{Contents}

CONTENTS

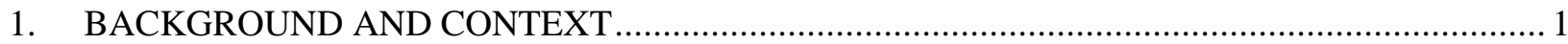

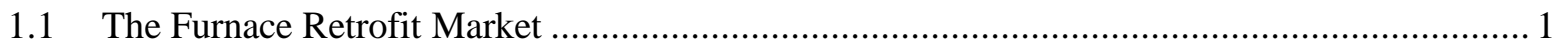

1.2 Analysis of Energy Flows in a Conventional Furnace …......................................... 2

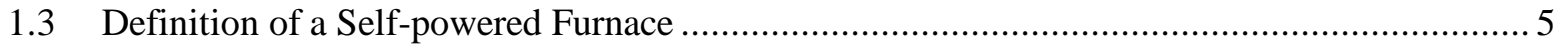

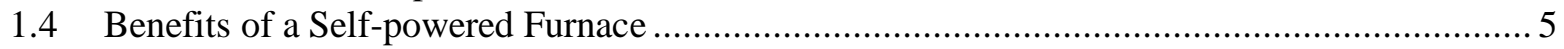

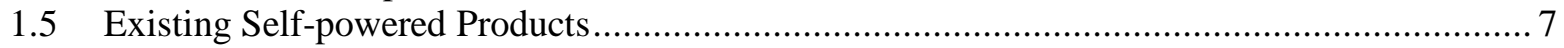

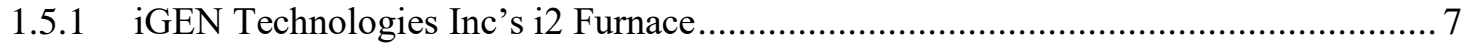

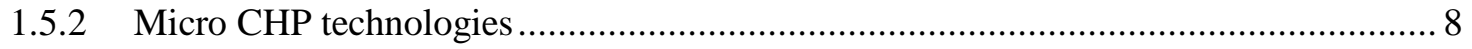

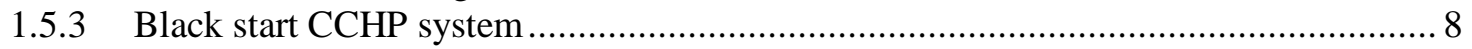

1.6 The Baseline System Against which to Compare ….......................................................... 9

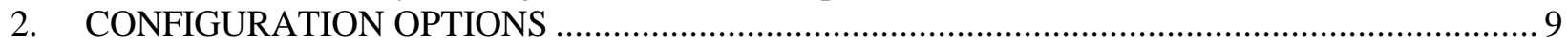

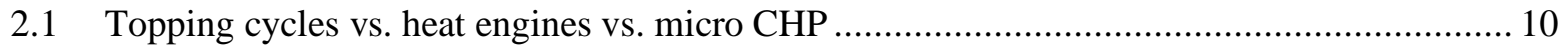

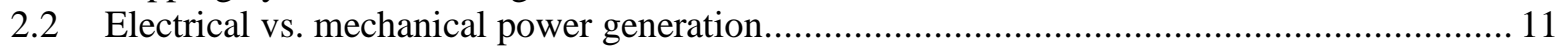

3. REQUIRED ATTRIBUTES FOR POWER CYCLE IN A SELF-POWERED FURNACE............. 11

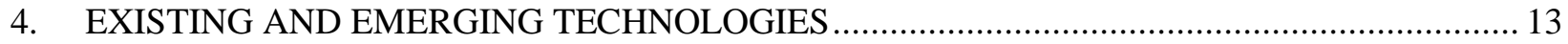

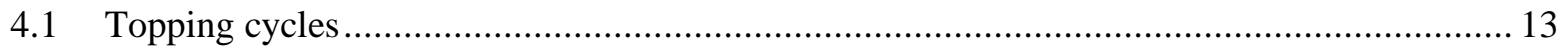

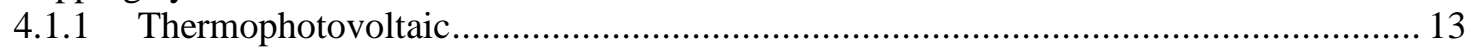

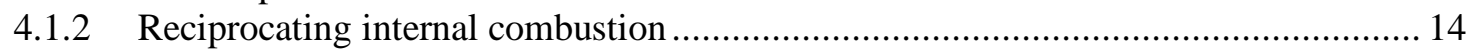

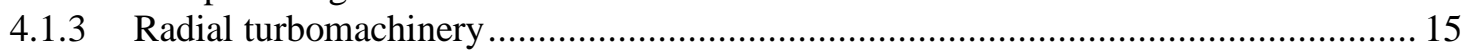

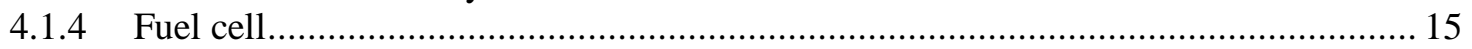

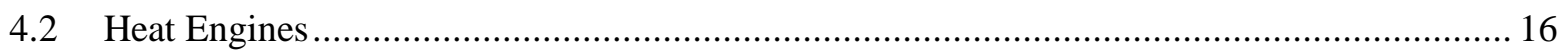

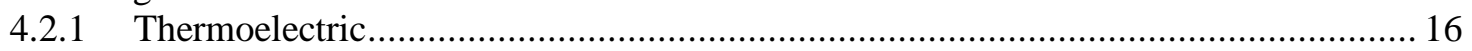

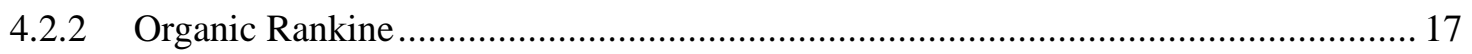

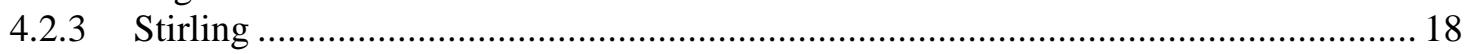

4.2.4 Thermo-magneto-electric (TME) generators .................................................. 18

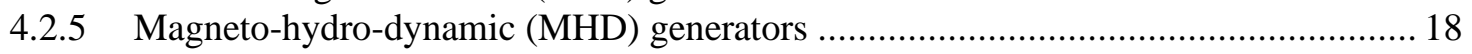

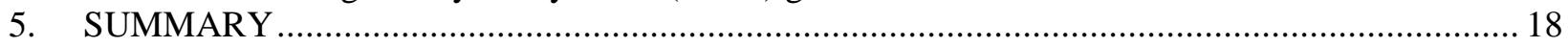

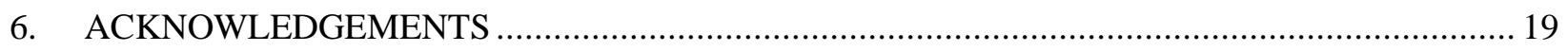

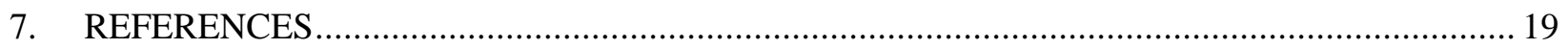




\begin{abstract}
Furnaces for residential space heating consume about $2.5 \%$ of all annual primary energy consumed in the US. Conventional furnaces utilize electricity from the electric grid to power blowers and other components. A self-powered furnace would utilize fuel energy to generate its own power, while rejecting the waste heat from the power cycle to provide additional useful building heating. Assuming the total energy use remains the same as for a conventional furnace, there are advantages in primary energy efficiency and operating cost. With no electrical connection to the grid, the self-powered furnace also improves resiliency to electric grid outages and reduces demand on the grid, which can be important during periods of peak heating. In addition, when unit size and venting type are maintained, a drop-in replacement with no incremental installation cost and increased potential for market adoption is achieved. In this work, the power generation requirements for such a drop-in-ready, self-powered furnace are analyzed, and available power generation technologies are surveyed.
\end{abstract}

\title{
1. BACKGROUND AND CONTEXT
}

\subsection{The Furnace Retrofit Market}

The 2015 Residential Energy Consumption Survey (RECS) data (US Energy Information Administration [EIA] 2017) show that natural gas furnaces are the most common primary space heating equipment used in all climate regions except the hot-humid region where heating needs are lower and electric furnaces are more prevalent (see Figure 1). In cold climates, the high cost of electric heating has often limited the use of heat pumps and other electric equipment; the use of other fuels such as distillate fuel oil and kerosene for space heating is declining (declined by $20 \%$ compared to the 2009 RECS survey results (Lawrence and Berry 2017). Overall, 38\% of American households (i.e., 45 million housing units out of 118.2 million) are heated by natural gas central furnaces, which represent a major potential market for the proposed technology. The remaining homes are $3.7 \mathrm{M}$ oil, $4.2 \mathrm{M}$ propane, $17.9 \mathrm{M}$ electric central furnace, and $12.1 \mathrm{M}$ heat pump. The oil and propane homes are also candidates for self-powered technology.

Total number of households per climate region (millions)

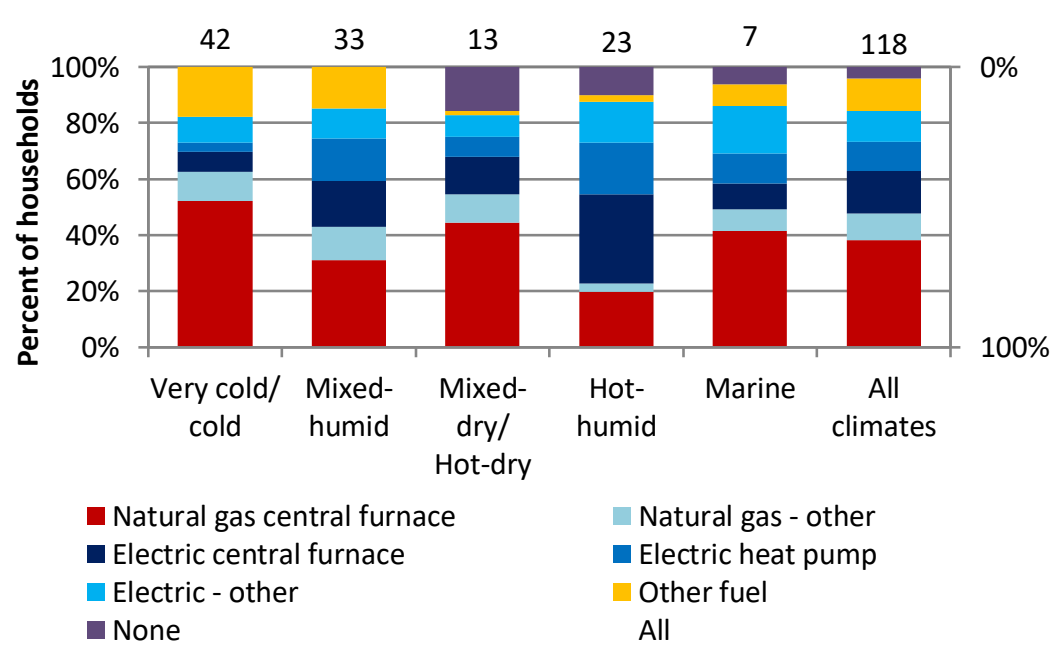

Figure 1: Space heating equipment by climate region, 2015

The Air-Conditioning, Heating and Refrigeration Institute (AHRI) historical shipment data (AHRI 2017) show that market share of air-source heat pumps shipments has been steadily increasing (Figure 2). 
However, gas furnaces represent most of the shipments in the US, with over 2.9 million units shipped in 2016, representing a strong potential opportunity for the proposed technology in the residential space heating market.

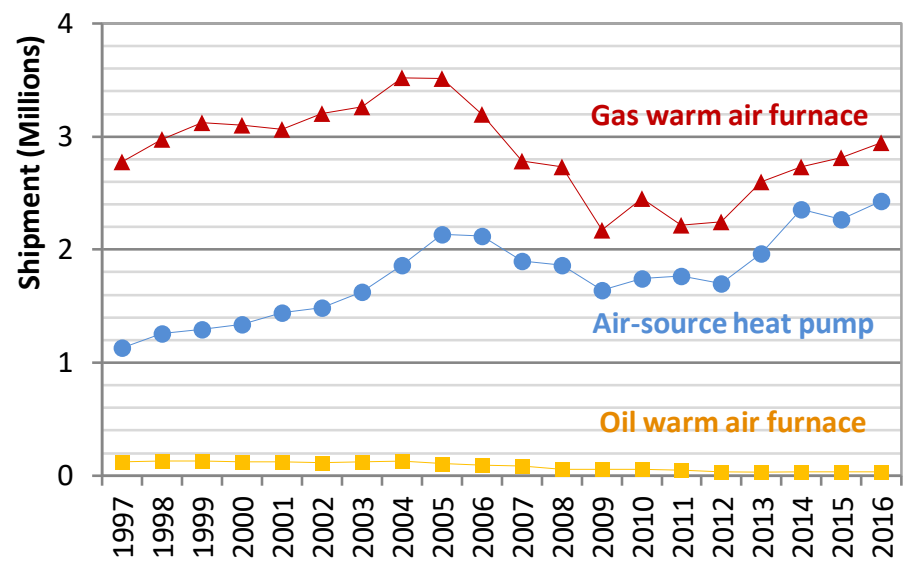

Figure 2: US Manufacturers' shipments of gas and oil furnaces and air-source heat pumps, 1997-2016

For non-weatherized gas furnaces (NWGF), the most common distribution channel is the replacement market. The final consumer in the replacement market is usually the homeowner, who is very influential in product selection (in the new construction market, a builder or general contractor is effectively the final purchaser). Replacements in kind (replacing a unit with a similar or identical product) are common, although premium products are also commonly sold in this market as replacements for older products that did not have premium features. Replacements represent approximately $75 \%$ of non-weatherized gas furnace sales (and 50\% of mobile home gas furnace sales) in the US (US Department of Energy 2015). For national impact analysis, DOE assumes an average lifetime of 21.5 years for gas-fired residential furnaces.

\subsection{Analysis of Energy Flows in a Conventional Furnace}

There are numerous types of energy flows in a furnace, as cataloged in Table 1. 
Table 1: Energy flows in a baseline 92 AFUE condensing furnace

\begin{tabular}{|c|c|c|c|}
\hline Energy type & Component & Energy flow rate $[\mathrm{kW}]$ & Notes \\
\hline \multirow[t]{2}{*}{ Chemical } & Natural gas & $23.4(80 \mathrm{kBtu} / \mathrm{h})$ & \\
\hline & $\begin{array}{l}\text { Non-ideal products of } \\
\text { combustion (HCs, CO, } \\
\text { NOx) }\end{array}$ & Negligible & \\
\hline \multirow[t]{3}{*}{ Thermal } & Primary heat exchanger & 18.7 & \\
\hline & $\begin{array}{l}\text { Secondary (condensing) } \\
\text { heat exchanger }\end{array}$ & 2.8 & \\
\hline & $\begin{array}{l}\text { Flue gas thermal energy } \\
\text { loss (vented outside) }\end{array}$ & 1.9 & \\
\hline \multirow[t]{2}{*}{ Rotational (shaft power) } & Supply air blower & $\sim 0.6$ & $\begin{array}{l}\text { Currently served by } \\
\text { AC electricity }\end{array}$ \\
\hline & Combustion air blower & $\sim 0.1$ & $\begin{array}{l}\text { Currently served by } \\
\text { AC electricity }\end{array}$ \\
\hline $\begin{array}{l}\text { Electrical (120 V } \\
\text { alternating current) }\end{array}$ & Blower motors, ignitor & $\sim 0.1$ & \\
\hline $\begin{array}{l}\text { Electrical ( } 24 \mathrm{~V} \\
\text { alternating current) }\end{array}$ & $\begin{array}{l}\text { Control signals } \\
\text { (e.g. thermostat, } \\
\text { solenoids, electrical } \\
\text { relay coils) }\end{array}$ & $\sim 0.01$ & \\
\hline $\begin{array}{l}\text { Electrical (5-24 V } \\
\text { direct current) }\end{array}$ & $\begin{array}{l}\text { Controls and digital } \\
\text { signals }\end{array}$ & $\sim 0.02$ & \\
\hline
\end{tabular}

A conventional condensing furnace has a heat exchange process that utilizes air at the adiabatic flame temperature of a lean combustion flame (approximately $2800^{\circ} \mathrm{F}$ ) to heat building air from about $70^{\circ} \mathrm{F}$ to about $120^{\circ} \mathrm{F}$. This is shown in Figure 3, both schematically (left) and as a temperature vs. cumulative heat transfer diagram (often referred to in the literature as a "T-Q diagram" or as a "pinch analysis" diagram.)
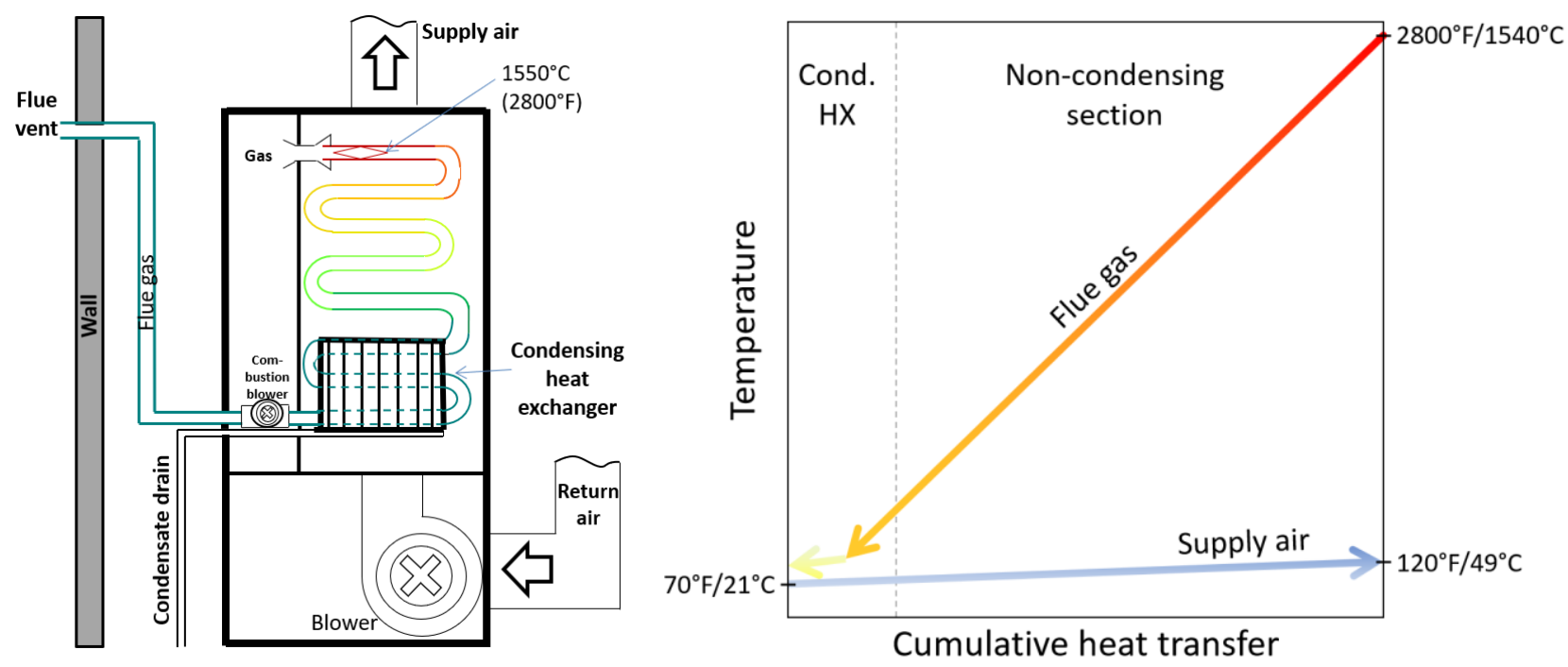

Figure 3: Conventional condensing furnace 
A Sankey view of a furnace is shown in Figure 4. In this diagram, energy flows are proportional to the thickness of arrow representing them. Most of the electrical energy is dissipated as useful heat since the blower and controls are positioned to dissipate heat to the supply air stream.

An observation is that $95 \%$ of the electrical requirements are for rotating parts (fundamentally speaking, mechanical loads and not electrical loads). See Section 2.2 (configuration options) for further discussion of this.

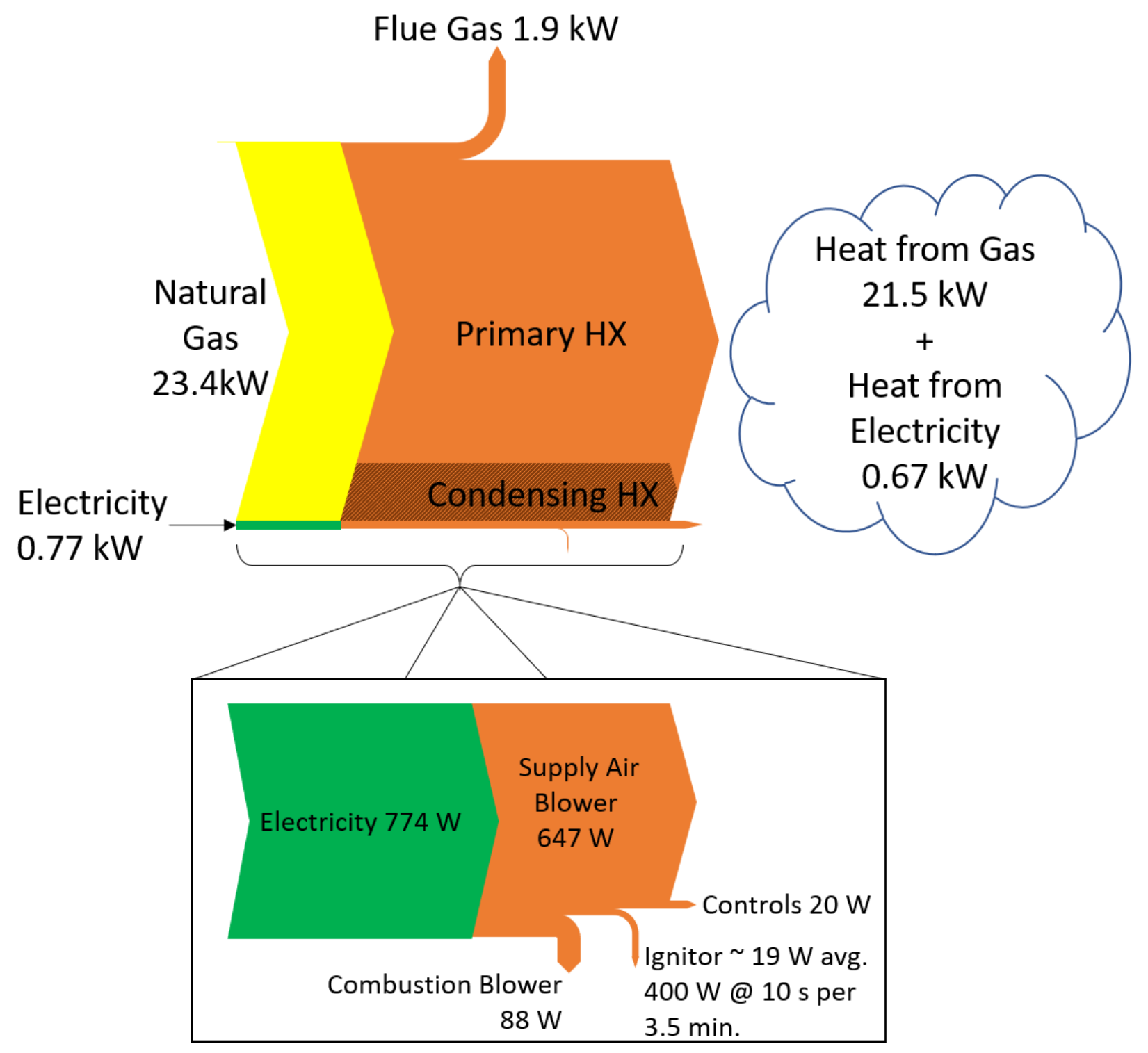

Figure 4: Sankey diagram of a typical 92 AFUE furnace 


\subsection{Definition of a Self-powered Furnace}

We can imagine a continuum of heating devices (see Figure 5), from an electrical power consuming device (e.g. furnace) to an electrical power exporting device (e.g. micro CHP). In the middle is the electrically neutral (self-powered) device.

From this perspective, there are a number of very common self-powered devices in the home: natural draft standing pilot gas storage water heaters, propane barbecues, wood stoves, fireplaces, and PVpowered calculators. However, the vast majority of space heating systems in the US are net electrical consumers (furnaces, heat pumps, boilers, etc.)

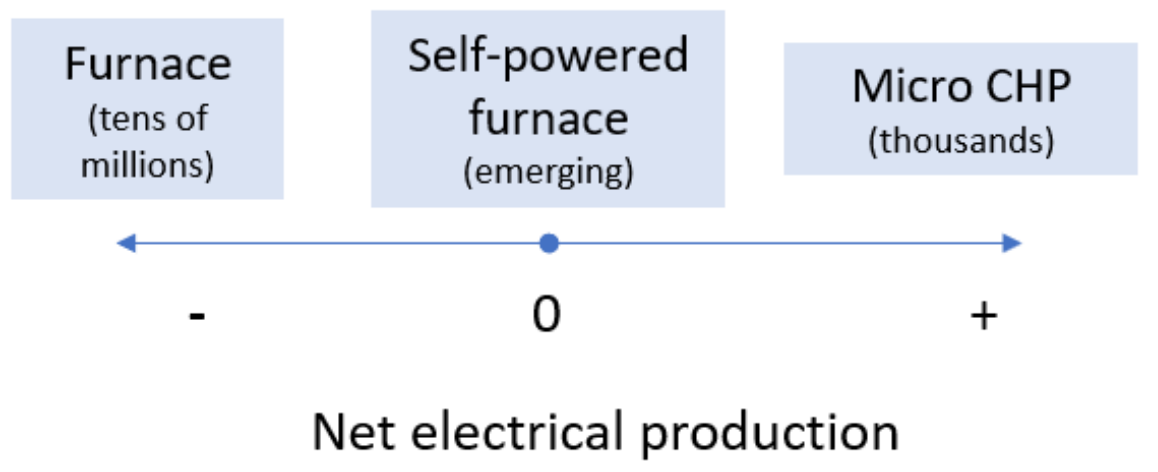

Figure 5: Heating devices on a continuum of net electrical production

A self-powered furnace would likely contain an electric battery to help with startup. For example, during the first minute of operation while the power generation cycle heats up, the battery provides energy for the ignitor and blowers. Once the power generation cycle reaches operating condition, it provides the power for ignitor, blowers, and battery recharging.

\subsection{Benefits of a Self-powered Furnace}

Market considerations. Considering the number of installed units, self-powered furnaces may be an effective way to scale up power generation technology. In contrast to micro CHP, which faces steep market barriers related to creating a brand new product category that previously did not exist, diverse utility tariffs, power export considerations, high capital cost, a lack of installer base, etc.; the self-powered furnace has the opportunity to be a straightforward drop-in sell for manufacturers and installers. In addition, it has the strong selling points of being a technology familiar to consumers, with added benefits of providing grid resiliency.

Energy efficiency. From the energy efficiency perspective, it also offers benefits. Adapting an expression from Gluesenkamp 2012, we can write the primary energy ratio (PER) of a furnace. The PER is the useful energy delivered divided by the primary energy consumed. Primary energy consumption for a furnace is the summation of natural gas consumed and primary energy consumption by the electric grid that supplies the furnace electrical loads. The furnace PER can be written as a function of its AFUE (defined as the useful heat produced per unit of higher heating value [HHV] fuel energy consumed, see Equation 1), its electrical consumption (represented by $\kappa$, the electrical consumption of the furnace per unit heat produced - see Equation 2), and the primary energy efficiency of the electric grid.

First, assuming that all electrical loads are eventually dissipated as lost heat, Equation 3 shows the PER of a furnace. If, on the other hand, we assume that all electrical loads are eventually dissipated as useful heat, we get the expression shown in Equation 4. These provide a bounded solution, with real furnaces falling 
in between the bounds. In practice, since most of the electrical consumption is dissipated in the blower, and the blower motor waste heat is entrained into the supply air flow, furnaces tend to approach the form given in Equation 4. There are other complicating factors, such as (a) short cycling results in transient storage of heat in the motor, which is later dissipated to the ambient, and (b) whether the furnace is installed in a conditioned, semi-conditioned, unconditioned, or outdoor space. Nevertheless, Equation 3 and Equation 4 provide relatively narrow bounds on the PER of a furnace. Equation 4 is more favorable towards conventional furnaces, and is adopted throughout this document.

$$
\begin{gathered}
A F U E=\frac{\text { Useful Heat }}{\text { HHV of Fuel Consumed }} \\
\kappa=\frac{\text { ElectricalConsumption }}{\text { InputRating } * \text { AFUE }} \\
P E R^{-1}=\frac{1}{A F U E}+\frac{\kappa}{\eta_{\text {grid }}} \\
P E R^{-1}=\frac{1}{A F U E(\kappa+1)}+\frac{\kappa}{\eta_{\text {grid }}(\kappa+1)}
\end{gathered}
$$

As an example, a typical furnace may consume $60 \mathrm{kBtu} \mathrm{HHV}_{\mathrm{H}} / \mathrm{h}(17.6 \mathrm{~kW})$ of fuel with an AFUE of $92 \%$ and consume $520 \mathrm{~W}$. Thus the value of $\kappa$ will be $520 /(17,600 * 0.92)=3.2 \%$. Plugging this into Equation 4, the fuel-only AFUE metric is reduced to a PER of $86 \%$.

In contrast, a self-powered furnace has a PER equal to its AFUE. This is because $\kappa=0$, and therefore Equation 4 reduces to Equation 5. This is illustrated further in Figure 6.

$$
P E R^{-1}=\frac{1}{A F U E}
$$

Equation 5 

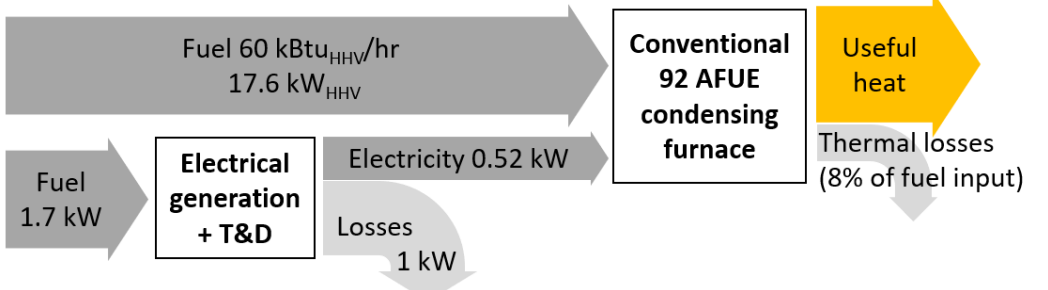

$$
\begin{gathered}
P E R^{-1}=\frac{1}{\operatorname{AFUE}(\kappa+1)}+\frac{\kappa}{\eta_{\text {grid }}(\kappa+1)} \\
\text { PER } \approx\left(\frac{1}{0.92 * 1.032}+\frac{0.032}{0.3 * 1.032}\right)^{-1}=0.86
\end{gathered}
$$
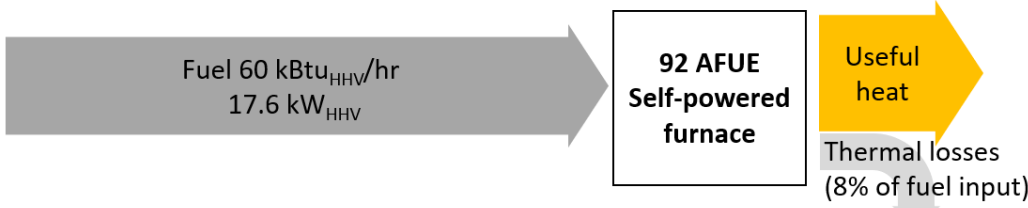

$$
\begin{aligned}
& P E R^{-1}=\frac{1}{\operatorname{AFUE}(\kappa+1)}+\frac{\kappa}{\eta_{\text {grid }}(\kappa+1)} \\
& \mathrm{PER} \approx\left(\frac{1}{0.92 * 1}+\frac{0}{0.3 * 1}\right)^{-1}=0.92
\end{aligned}
$$

Figure 6: Comparison of overall Sankey diagrams for conventional and self-powered furnaces, showing the difference in primary energy ratio.

Seen another way, for a fixed AFUE, PER is shown as a function of electrical consumption for a 60 $\mathrm{kBtu} / \mathrm{h}$ furnace in Figure 7.

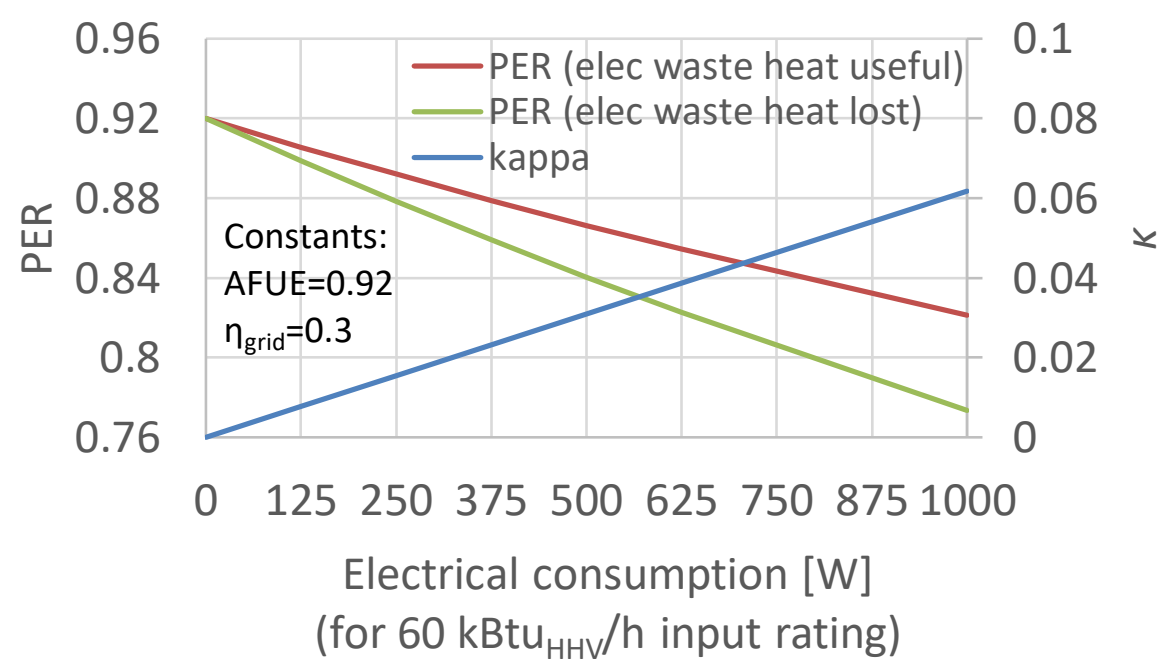

Figure 7: PER is a strong function of the electrical consumption, a trend that is not captured by the AFUE metric. This figure assumes that all electrical waste heat is dissipated as useful heat into the air stream.

\subsection{Existing Self-powered Products}

\subsection{1 iGEN Technologies Inc's i2 Furnace}

The company iGEN is marketing a self-powered furnace in Canada. Few details are available, but it appears to use a proprietary generation technology. Some images from their public online presence are 
shown in Figure 8. The solution being offered is not a drop-in replacement, appearing to require a custom installation, and cost data was not readily available.
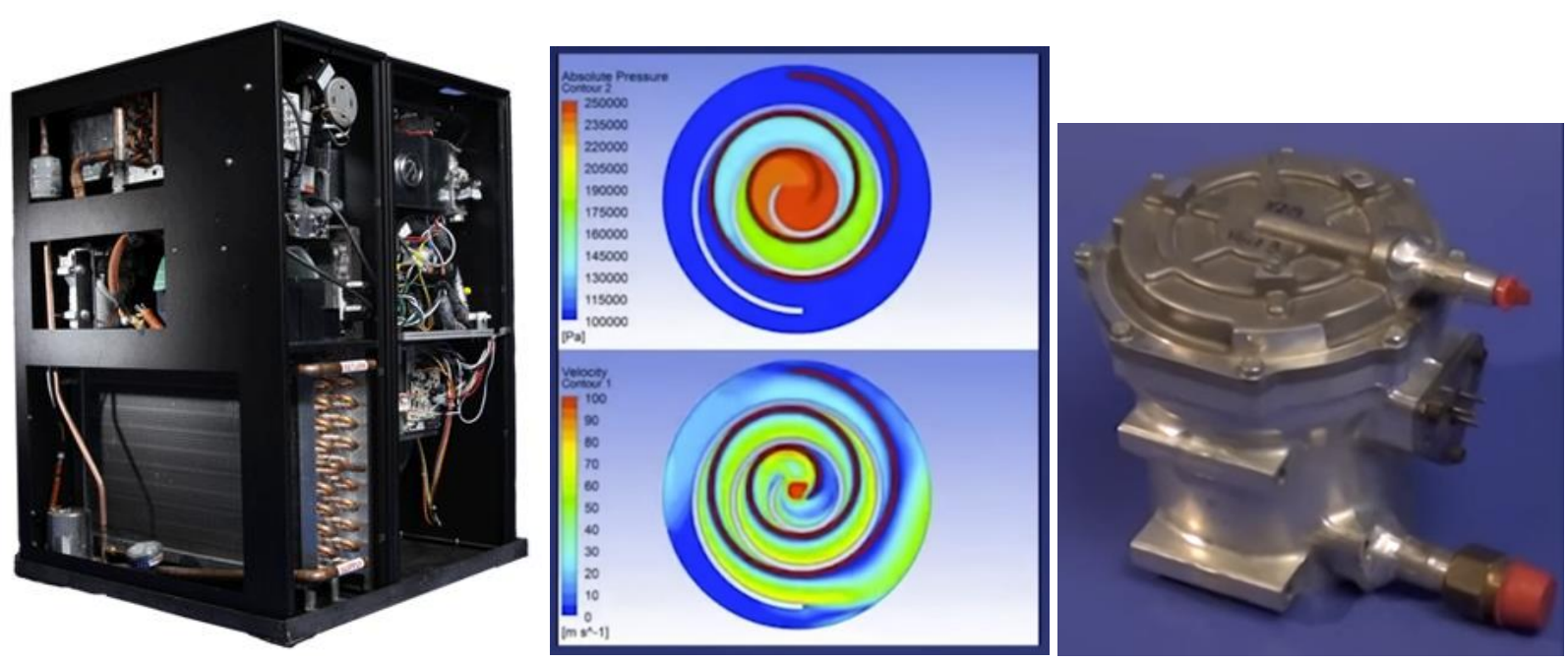

Figure 8: Images from iGEN's website and YouTube video

\subsubsection{Micro CHP technologies}

There are 3 main technologies of m-CHP systems: internal combustion engines (ICE), external combustion engines (ECE) and no-combustion (NC). The market of micro-CHP has been dominated by ICE technology because of their maturity and ease of scaling the engines in size. ICEs however require frequent maintenance and generally are noisier than the other technologies. Over the past decade there has been a rising interest in fuel cell (NC) technology, especially in Europe and East Asia. Fuel cells are easier to scale down in size than ICE, they produce practically no emissions and they do not have moving parts, in turn they are quiet, but their response time is longer than ICE. They have historically cost more than ICE but that might change in the near future as their market is growing steadily. Stirling (ECEbased) micro-CHP's exist but have only limited market share. Stirling engines theoretically cost less and are lighter than ICE but have longer response times and generally their reliability and durability are still problematic. Micro-turbine-CHP is another ECE technology for micro-CHP. Micro-turbines are lighter, and their response time is shorter than ICE and they produce less $\mathrm{NO}_{\mathrm{x}}$. Their major disadvantages are their high initial cost, high maintenance cost and their relatively shorter life. Scaling micro-turbine to submicro (sometimes referred to as Nano) levels $(<10 \mathrm{~kW})$ is extremely challenging and costly. Using automotive turbocharger components as basis for the development of micro (or Nano) turbines greatly reduces the cost and the development needed, especially if low efficiencies are acceptable.

\subsubsection{Black start CCHP system}

In a joint project among IntelliChoice Energy, Department of Defense and Southwest Gas Corporation, a combined cooling heating and power product was designed. The unit was designed to be able to start without electric supply from the grid, and hence it was given the name "Black Start". One prototype was built that provided cooling/heating, $1.5 \mathrm{~kW}$ electric power output and $50 \mathrm{kBtu} / \mathrm{hr}$ in water heating. In April 2013, the prototype was installed at Nellis Air Force Base in Las Vegas. It served a 1,500 sq ft office building. The demonstration ended in June 2014. Over the duration of the demonstration, the unit ran for 
2,948 hours and produced 85,621 kBtu in space conditioning, 70,752 kBtu in hot water and 3,386 kWh in electricity.

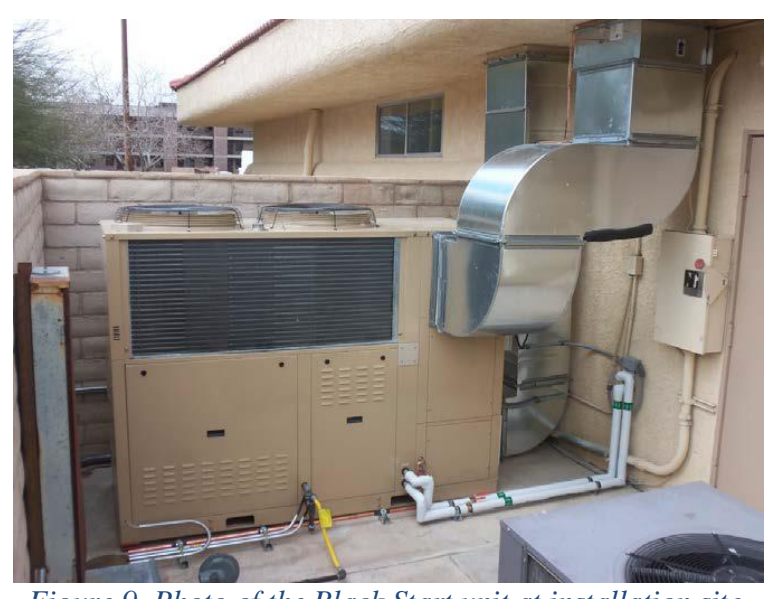

Figure 9. Photo of the Black Start unit at installation site.

\subsection{The Baseline System Against which to Compare}

From a consumer point of view, a self-powered furnace would have a few key competitors, as shown in Table 2.

Table 2: Self-powered furnace and key alternatives from a consumer perspective. Green: best. Red: worst. Yellow: intermediate. If first cost is kept low, the self-powered furnace will be the highest performing option.

\begin{tabular}{|l|l|l|l|l|}
\hline \multirow{2}{*}{ System type } & \multicolumn{3}{|c|}{ Performance } & First cost \\
\cline { 2 - 5 } & $\begin{array}{c}\text { Duration of } \\
\text { heating during } \\
\text { power outage }\end{array}$ & $\begin{array}{c}\text { Energy } \\
\text { cost }\end{array}$ & $\begin{array}{c}\text { Maintenance } \\
\text { requirements }\end{array}$ & \\
\hline Baseline furnace & None & High & None & Lowest \\
\hline Baseline with backup generator & Unlimited & Highest & High & High \\
\hline Baseline with backup battery & Limited & High & Low & High \\
\hline Self-powered furnace & Unlimited & Lowest & None & TBD \\
\hline
\end{tabular}

\section{CONFIGURATION OPTIONS}

The basic options for how to arrange a power generation cycle inside a furnace are shown in Figure 10.

The conventional efficiency definition for power generation is shown in Equation 6.

$$
\eta_{\text {conventional }}^{\text {power cycle }}=\frac{\text { useful energy out }}{\text { fuel energy in }}
$$

Equation 6

In the self-powered furnace application, since chemical energy in the exhaust can still be utilized downstream by being combusted in the main burner, a more relevant definition for the power generation cycle in a self-powered furnace is shown in Equation 7. 
$\eta_{\text {power cycle }}^{\text {pow }}$

$\eta_{\text {self-powered furnace }}$

Equation 7

$$
=\frac{\text { useful energy out }}{(\text { fuel energy in })-(\text { chemical energy remaining in exhaust })}
$$

This unconventional definition of efficiency may provide opportunities for technologies that would benefit from a rich and/or incomplete combustion.

Traditionally, engine design is a complex multi-objective balance among efficiency, cost, longevity, system footprint, acoustic noise/vibration/harshness, and other design goals. By relaxing the efficiency constraint, constraints on the engine designer are relaxed, widening the design domain and providing opportunities for creative new designs.

\subsection{Topping cycles vs. heat engines vs. micro CHP}

Figure 10 illustrates three configuration options for a self-powered heating device. In every case, a power generation cycle is required, which is depicted in the figure by a green circle.

The first option is referred to here as "micro CHP" because of its similarity to micro combined heat and power systems. All the fuel is consumed by the power generation cycle, and all heat provided to the supply air is rejected from the power cycle.

In a topping cycle, the generator directly consumes some of the fuel, and provides its rejected heat to the supply air. In an extreme case, if it consumes all the fuel, it operates like a micro-CHP device.

In the heat engine configuration, all the fuel is combusted in a burner, and some of the resulting thermal energy enters the heat engine power cycle, where work is produced and rejected heat is provided as useful heat to the building supply air.

\section{Micro CHP}

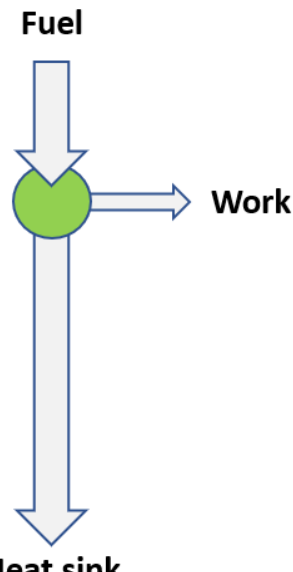

Topping cycle

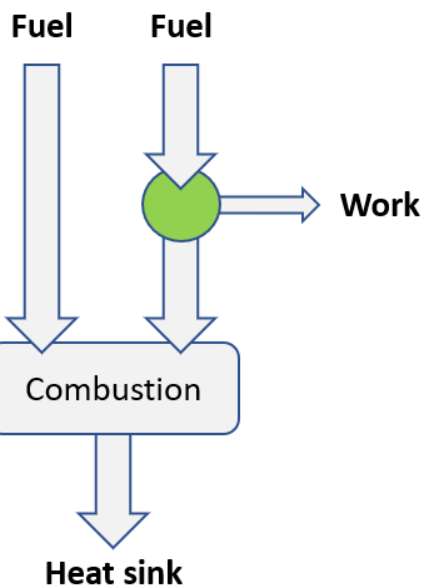

Heat Engine

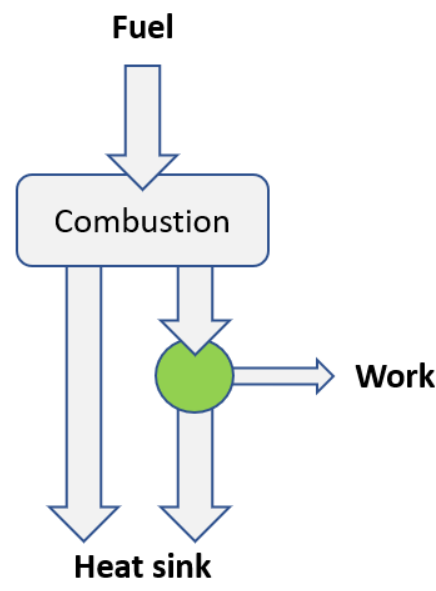

Figure 10: Configuration options for integrating a power generation cycle (green circle) in a furnace, and comparison to micro CHP. In topping cycles, fuel is sent directly to the generator, whereas in heat recovery cycles the generator accepts some postcombustion heat. 
It is important to notice that, in the topping cycle, the exhaust of the power cycle is "post combusted" in the main burners. Thus, remaining chemical energy in the power cycle exhaust (CO, unburned hydrocarbons, or other oxidizable products of partial combustion) can be re-burned in the main burner. Highly oxidized compounds such as NOx would not be reduced by this simple post combustion. In the heat engine configuration, emissions remain the same as for the baseline conventional furnace.

\subsection{Electrical vs. mechanical power generation}

As noted in the earlier analysis of furnace energy flows, about $95 \%$ of the electrical requirements are for two rotating parts. The potential exists for a power generation technology to deliver $\sim 700 \mathrm{~W}$ of shaft power, with only $\sim 40 \mathrm{~W}$ of electrical power required. One challenge with this approach would be the startup sequence, where a motor may be required to operate the combustion blower until the shaft power production is produced. For a rapid startup technology such as internal combustion, this challenge could be readily accommodated in a practical design.

\section{REQUIRED ATTRIBUTES FOR POWER CYCLE IN A SELF-POWERED FURNACE}

The implementation of a power cycle in a furnace imposes a set of constraints to make the implementation practical and commercially viable. In the following paragraph, we will categorize and summarize these constraints. The main requirements and metrics are summarized in Table 3.

- Cost: the cost of the power cycle implementation must be low enough to ensure the commercial viability of the final product. Appliance market is extremely competitive with thin profit margin. The addition of this sub-system must pay for itself in relatively short period of time ( $\sim 2$ years) to be commercially successful.

- Volume (space): like other appliances, furnaces have typical dimensions. This ensures that appliances fit within typical homes. The addition of the power cycle implementation, ideally, must not affect the size of the furnace; footprint and overall volume. Hence, the implementation of the power cycle must operate at a high-enough efficiency to ensure that it fits within typical furnace.

- Noise emissions: due to their indoor placement, residential appliances have less tolerance for noise than outdoor equipment. The power cycle implementation in the furnace must not add to the overall noise emission of the furnace.

- Efficiency: in this implementation, efficiency constraints are relaxed. This is because the entire implementation could be fully contained in the furnace. Therefore, any rejected heat will be recovered into the air stream being heated, and will not be wasted. This enables the utilization of technologies that are conventionally considered undesirable due to their low efficiency. However, lower efficiency will directly influence the size, and cost, of a certain implementation. Hence, a low efficiency technology is acceptable as long as it satisfies the other attributes discussed in this section.

○ Opportunity for technologies not conventionally considered desirable

- Efficiency not important per se (only to the extent it influences heat exchanger area, i.e. cost)

- Emissions: since they will be measured at the exhaust point to ambient, emissions of the topping cycle can be higher than what is mandated for the eventual point of measurement "tail-pipe emissions". This enables the utilization of technologies that are considered too dirty, such as 2stroke engines, or ones that are made too complex by being designed for clean emissions, such as 
Solid Oxide Fuel Cells. $\mathrm{NO}_{\mathrm{x}}$ emissions are an exception since they will not be reduced in secondary combustion.

- Emissions of a topping cycle can be fed to burner (may enable technologies conventionally considered "too dirty" (2-stroke ICE?), or made too complex by being designed for clean emissions [SOFC?])

- NOx produced by topping cycle, however, would not be reduced in the furnace burner

- Start and stop ability (lots of on/off cycles in furnace application): furnaces, by nature, experience a high rate of ON/OFF cycles. The topping cycle heat engine must be able to start up and reach full output level in short time. To help reduce cycling, system level design of the furnace will likely incorporate variable speed blower and variable combustion rate.

- system level design will likely incorporate variable speed blower and variable combustion to minimize cycling rate

- Ability to start on low pressure natural gas: furnaces today run on natural gas pressure typically supplied by residential regulators ( 14.9 millibars/0.25 psi.) Therefore, the topping cycle engine must be able to either intake fuel at such pressure, or also power a gas compressor.

- Scale - half kW scale: combined electrical and mechanical load in a furnace is typically on the order of 500 Watts. The topping cycle implementation must be scaled down to this power level while satisfying all other constraints.

- Type of power output: in a furnace, rotational power is needed to run the air blower and combustion blower while electrical power is needed to run the electronics needed for operational control. Electrical power requirement represents $\sim 10 \%$ of the total power (in Watts.) Rotational power generated by the topping cycle implementation could directly drive the blowers.

$\circ$ electrical

- Rotational power output could be used directly for $99 \%$ of furnace load

- $\sim 40 \mathrm{~W}$ combustion blower

- $\sim<20 \mathrm{~W}$ controls ( $\sim 5 \mathrm{~W}$ is typical for a conventional furnace, but more controls may be needed)

- ignitor high amperage, but very short duration ( $\sim 5$ per cycle $)$

- $\quad 5 \mathrm{~W}$ battery charging and self-discharge

- Longevity: homeowners typically expect their furnaces to last for 12 years at least. Any topping cycle implementation must have as long expected useful life. Otherwise, replacement of topping cycle implementation becomes a barrier to the commercial success of self-powered furnaces.

- Maintenance requirements: furnaces typically run with minimal, to no, maintenance. A topping cycle implementation must be designed to maximize maintenance intervals. From past experience with gas engine driven heat pumps, 10,000-hour maintenance interval is acceptable.

- Venting - compatible with what is being replaced (condensing): self-powered furnace must allow drop-in replacement of conventional counterparts. This ensures a larger available market of the technology. This necessitates that venting requirements of the self-powered furnace are kept the same as conventional ones.

- Maintain conventional supply temperature, with very short heat up delay ( $10 \mathrm{~s})$ : a critical parameter of space heating appliances from comfort perspective is supply temperature and the time it takes to reach that temperature. Conventional furnaces can provide relatively high supply air temperature $\left(\sim 55^{\circ} \mathrm{C}\right)$ within short time $(\sim 10$ seconds.) Self-powered furnaces must be capable of providing the same supply temperatures within the same period to ensure full compatibility with conventional replacements. 
Table 3. Summary of required attributes of power cycle.

\begin{tabular}{|l|l|}
\hline Attribute & Requirement \\
\hline Cost & Low enough to pay for itself in $~ 2$ years \\
\hline Volume & $\begin{array}{l}\text { Should not affect the overall dimension of typical } \\
\text { furnace }\end{array}$ \\
\hline Noise & Below $62 \mathrm{~dB}$ \\
\hline Efficiency & $\begin{array}{l}\text { No constraint as long as it allows the } \\
\text { implementation to meet size requirement }\end{array}$ \\
\hline Emissions & $\begin{array}{l}\text { CO and HC emissions can be higher than } \\
\text { regulation since they will be post-combusted. } \mathrm{NO}_{\mathrm{x}} \\
\text { must be within regulatory limits. }\end{array}$ \\
\hline Cycling & Must handle 3 cycles/hr \\
\hline Fuel pressure & $\begin{array}{l}\text { Must be able to run on } 0.25 \text { psi gas supply } \\
\text { pressure }\end{array}$ \\
\hline Capacity & $\begin{array}{l}500 \text { Watts rotational power }+20 \text { Watts electric } \\
\text { power }\end{array}$ \\
\hline Longevity & 12 years at least \\
\hline Maintenance & Every 10,000 hours or more \\
\hline $\begin{array}{l}\text { Final supply air } \\
\text { temperature }\end{array}$ & $55{ }^{\circ} \mathrm{C}$ within 10 seconds \\
\hline
\end{tabular}

\section{EXISTING AND EMERGING TECHNOLOGIES}

\subsection{Topping cycle configuration options}

\subsubsection{Thermophotovoltaic}

A thermophotovoltaic (TPV) generator refers to an innovative system able to convert the radiant energy emitted from a hot process or combustion source into electrical energy. This conversion is realized most often by designing the radiant source to preferentially emit radiant energy at certain wavelengths (usually in the infrared spectrum) that can be relatively efficiently transformed to electrical energy using specialized photovoltaic materials. With this concept, the device is designed to achieve "spectral matching" between the radiant source and the bandgap (wavelength range for useful conversion) of the photovoltaic cells for greater efficiency than could be obtained via "normal" radiant emission. Some TPV schemes also include a spectral filter between the radiant source and the photovoltaic portion. The radiating hot ceramic or other material will generally have a surface composition designed for maximizing certain wavelength bands.

Relevant TPV systems feature very hot emitting materials $\left(800-1200^{\circ} \mathrm{C}\right.$ or higher temperatures) which may be part of a burner system or directly heated by a burner. The material must be robust to this environment and the photovoltaic cells may need some protection from heat, deposition and degradation. The emitting material, photovoltaic cells and spectral filters may require exotic and highly engineered materials. Because this is a radiative transfer system, the geometry must be designed for a good view factor between the emitter and receiving photovoltaic cells. Research and development work continues to be done on TPV systems but no commercial applications are known at this time [Ferrari et al. 2014]. 
In implementing this technology to self-powered furnaces, the electrical output from the TPV would be used to power the blower and associated electronics (thermostat, control board, etc). Of note is the U.S. Patent 6284969 B1 - Hydrocarbon fired thermophotovoltaic furnace, held by JX Crystals Inc. and associated concepts including their portable TPV Battery [Fraas et al. 2011]. The TPV Battery concept is a self-contained propane burner and TPV electric generator. Other projects have reported impressive power output from TPV system based on modeling, however no physical product has emerged from much of this research [Nelson 1996]. A recent research project with experimental results incorporated TPV into the exhaust flue of a residential boiler. The exhaust gases heated the emitter to $1265^{\circ} \mathrm{C}$ and produced a total power output of $246 \mathrm{~W}$ [Qui and Hayen 2014].

\subsubsection{Reciprocating internal combustion}

Traditionally, design of spark ignition (SI) or diesel internal combustion engines (ICE) is a complex multi-objective balance among efficiency, cost, longevity, system footprint, acoustic noise/vibration/harshness, and other design goals.

However, in the self-powered furnace application, the constraints are dramatically different from the conventional applications for ICEs. The presence of post combustion practically eliminates the constraints on the emissions in the exhaust of the engine. This application could also afford lower efficiency engines, since heat lost from the engine can be recovered to heat the air. Therefore, examining existing reciprocation engines for the current application of interest is a logical path. Also, it may be feasible to create a new engine design dedicated to self-powered furnaces, since relaxation of design constraints widens the design domain in a way that gives the engine designer more freedom to be creative.

By relaxing the efficiency and emissions constraints, the engine designer has considerably more freedom in design, widening the design domain and providing opportunities for creative new designs.

\section{Purpose-Built Conventional NG SI ICEs}

The use of NG is quite favorable to (4-stroke) SI ICEs, due to the generally high-octane rating of NG making it an excellent spark engine fuel. Because of the nominally $1 \mathrm{kWe}$ or less requirement, a single cylinder design would be an obvious consideration. Generally, the use of conventional ICEs for micro CHP applications must involve overcoming barriers/requirements concerning noise, vibration, durability, maintenance, cost and emissions. A very high-quality reciprocating engine is traditionally needed to meet such requirements.

Small scale ICE-based CHP systems compatible with NG have been marketed or are currently marketed in some parts of the world (Honda 2018, Taie et al. [in press], Aisin 2018). Honda released a household cogeneration system in 2003, which is a combined hot water and heating unit that nominally produces 1 $\mathrm{kWe}$, but is no longer marketed in the US (Taie et al. [in press]). Another nominally $1 \mathrm{kWe}$ ICE-based system is the Aisin COREMO, sold in Japan that produces between 0.5 and $1.5 \mathrm{kWe}$ (Aisin 2018). This system appears to be for home applications with circulating hot water heat. These both feature 4 stroke single-cylinder SI engines. A 4-stroke engine designed specifically for our application would make use of the relaxed emissions and efficiency constraints.

\section{Rotary engines}

The concept of a small rotary engine for unmanned aircraft or small generators has been examined in the past (Theiss et al. 2000, Fry et al. 1997) and at least one US company, LiquidPiston, Inc., is currently developing such an engine (LiquidPiston 2018, Littera et al. 2015) with support from military 
sponsorship. Advantages are the potential for a relatively low noise and vibration design. The engine design is claimed to be compatible with NG fueling and applications as small as $1 \mathrm{~kW}$. Generally, rotary engine designs are of interest for excellent power-to-weight ratio, which, along with the lower noise and vibration, suits our application well. A UK company claims to produce a $3.7 \mathrm{~kW}$ shaft output rotary engine for such purposes (AIE UK 2018).

\section{Small two-stroke piston engines}

A number of small two-stroke and four-stroke engines rated from $0.75 \mathrm{~kW}$ shaft output and larger have been marketed for applications such as garden power tools (blowers, string trimmers, small chain saws, etc.). These gasoline engines generally are made to last only a short time ( 50-250 hrs) (West et al. 2008) and extensive further development would be needed for a long-life application. The short lifetime is a major drawback for our application from market acceptance perspective. Two-stroke engines have unique lubrication and emission characteristics that are traditionally challenging to overcome. In our applications, emission levels are not a deciding factor but consumption of oil is a key drawback, as it increases the maintenance requirements, likely beyond what a consumer would accept.

Use of two-stroke "hobby" engines designed for recreational model airplanes and other uses has been proposed for micro-CHP and small generators. These are generally low-quality devices, having drawbacks concerning efficiency (which can be less than 10\%), durability, lubrication, emissions and the requirement of special fuels (West et al. 2008). It is notable that small two-stroke engines have complex "breathing" fluid mechanics and tend to operate best in narrow speed bands (West et al. 2008).

\subsubsection{Radial turbomachinery}

Traditionally, the main challenge to scaling down micro-turbines in size is obtaining acceptable efficiencies. The small size 1) results in low flow velocities through the turbine passages which increases the viscous losses, 2) tip clearance become relatively high resulting in higher relative windage losses, 3) area-to-volume ratio becomes larger resulting in higher heat losses and 4) parasitic losses becomes relatively higher. At power level of $\sim 1 \mathrm{~kW}$, dimensions of the turbine and compressor become so small that the rotational speed have to be on the order of several 100,000 rpm. These challenges have limited the applicability of small micro-turbomachinery. Since they are not mass produced, their cost is high.

In the self-powered furnace application, the efficiency constraint can be significantly relaxed. A low efficiency, low cost turbomachinery can be used. A paper published in Visser (2010) reported on the experimental performance results of a $3 \mathrm{~kW}$ micro-turbine CHP. The CHP was constructed from off the shelf turbomachinery built for the automotive industry. The prototype produced $2.7 \mathrm{~kW}_{\mathrm{e}}$ at $12.2 \%$ fuel-toelectricity efficiency. Automotive turbomachinery is mass produced and could be adapted to the selfpowered furnace application at a substantially reduced development cost.

\subsubsection{Fuel cell}

Fuel cells have low maintenance requirements and emits almost no noise because they have no moving parts. These two characteristics are especially attractive to self-power furnace. Currently, there are two mature fuel cell technologies; Proton Exchange Membranes Fuel Cell (PEMFC) and Solid Oxide Fuel Cell (SOFC.) Several fuel cells are commercially available in the range of 500 to 5,000 Watt range.

AISIN developed an SOFC with electricity generating range of 50 to 700 Watts that runs on natural gas as well as propane. Viessmann and Panasonic jointly developed a small $750 \mathrm{~W}_{\mathrm{e}} / 1 \mathrm{~kW}_{\text {th }}$ fuel cell. The fuel 
cell is used in the VITOVALOR domestic water heater ${ }^{1}$. Tokyo Gas has developed, and distributes, a 700 $\mathrm{W}_{\mathrm{e}}$ PEMFC. A recent paper reported testing results of a $1.5 \mathrm{~kW}_{\mathrm{e}} \mathrm{SOFC}$ micro-CHP Hormaza (2017).

Recently, an ORNL team has proposed to develop Nickel Zirconia anode, Zirconia electrolyte and Lanthanum-based material cathode fuel cell that runs on natural gas. In this proposed design, steam reforming takes place on the cells themselves. This eliminates the need for a reformer which reduces the size (volume) of the whole fuel cell system and reduces its cost. PEMFC technology is more mature, less expensive, and more durable, but requires a reformer which adds extra cost and requires larger footprint.

SOFCs run at much higher temperatures than PEMFCs, but they take much longer time to reach their running temperature before power can be extracted, which makes them less suitable to a self-powered furnace since furnaces usually run at high cycling rate. Because of their elevated running temperatures, $\sim 700^{\circ} \mathrm{C}$, special system construction materials are required. If they are run at lower temperature, $\sim 600^{\circ} \mathrm{C}$, their efficiency is reduced but the cost of the system is significantly reduced as well since stainless steel could be used.

In general, fuel cells offer many options to be explored. Some of them are already produced commercially, though they may not be off-the-shelf. PEMFCs or the ORNL proposed fuel cell are more suitable to deployment in a self-powered furnace than SOFCs.

\subsection{Heat engine configuration options}

\subsubsection{Thermoelectric}

Thermoelectric (TE) material-based electric generators are a candidate for recovering energy from heat, including "waste" heat, via direct conversion of transferred heat energy to electricity. Heat transfer through these special materials causes an electromotive force and current flow, which is the principle of common thermocouple temperature measuring instruments. The capability of TE power generation is fundamentally dependent on the TE material properties and the induced thermal gradient. A great many materials, almost all being intermetallic/metallic alloys, have been explored and used for TE research development and applications; with different composition types targeting different temperature ranges [Twaha et al. 2016, Gaultois et al. 2013]. Two differing, but usually similar, materials are paired in an electrical circuit that produces voltage via to the thermal gradient they are subjected to. One in the pair induces the voltage opposite to the other. This pair or "couple" is matched to withstand the temperatures and conditions expected for the application. The cost of these intermetallic semiconductor type materials can be quite high in some realized systems due to the use of rare elements and high degrees of processing.

TE materials are generally fashioned into small (example: $10-20 \mathrm{~cm}^{2}$ and $5 \mathrm{~mm}$ thickness) unit modules that can produce electric power when subjected to a large thermal gradient. Designs of thermoelectric generators (TEGs) normally include a large number of modules combined into a carefully designed and engineered heat exchanger unit, appropriate for using a specific heat source such as process heat, a dedicated burner or other combustion exhaust heat. In some cases a liquid coolant is used for the cold side. The modules are also connected electrically and often with a power converter/conditioner to meet the electrical requirements. The innate ability of the modules to produce power from a thermal gradient is a broad and continuing focus of research and development [Twaha et al. 2016, Gaultois et al. 2013, Szybist et al. 2018], and the design of appropriate TEGs for specific applications is a considerable challenge.

${ }^{1}$ https://www.viessmann.co.uk/en/residential-buildings/combined-heat-and-power-generation/micro-chp-unit-based-on-a-fuel$\underline{\text { cell/vitovalor-300p.html }}$ 
Commercialized TEGs are marketed for niche applications [Gentherm 2018, Marlow 2018, Thermal Electronic Corp 2018], with the overall market currently being relatively small. A North American based company, Gentherm Global Power Technologies, produces a variety of NG fired units including designs in the $500 \mathrm{~W}$ output range using about $21 \mathrm{~kW}$ of NG flow (chemical energy). This roughly matches the design criteria for a self-powered furnace. Note the electrical energy/fuel energy efficiency reported (calculated from company specification sheets) is roughly $2.1-2.6 \%$ for this application using lead-tintelluride type TE materials. The Gentherm website states that there have been more than 25,000 Gentherm Global Power Technologies' TEGs installed in 55 countries. A few other companies are known to market TE devices of some type (Marlow, Thermal Electronics Corp.) with less obvious applicability.

ORNL previously proposed a thermoelectric furnace, with the layout shown in Figure 11.
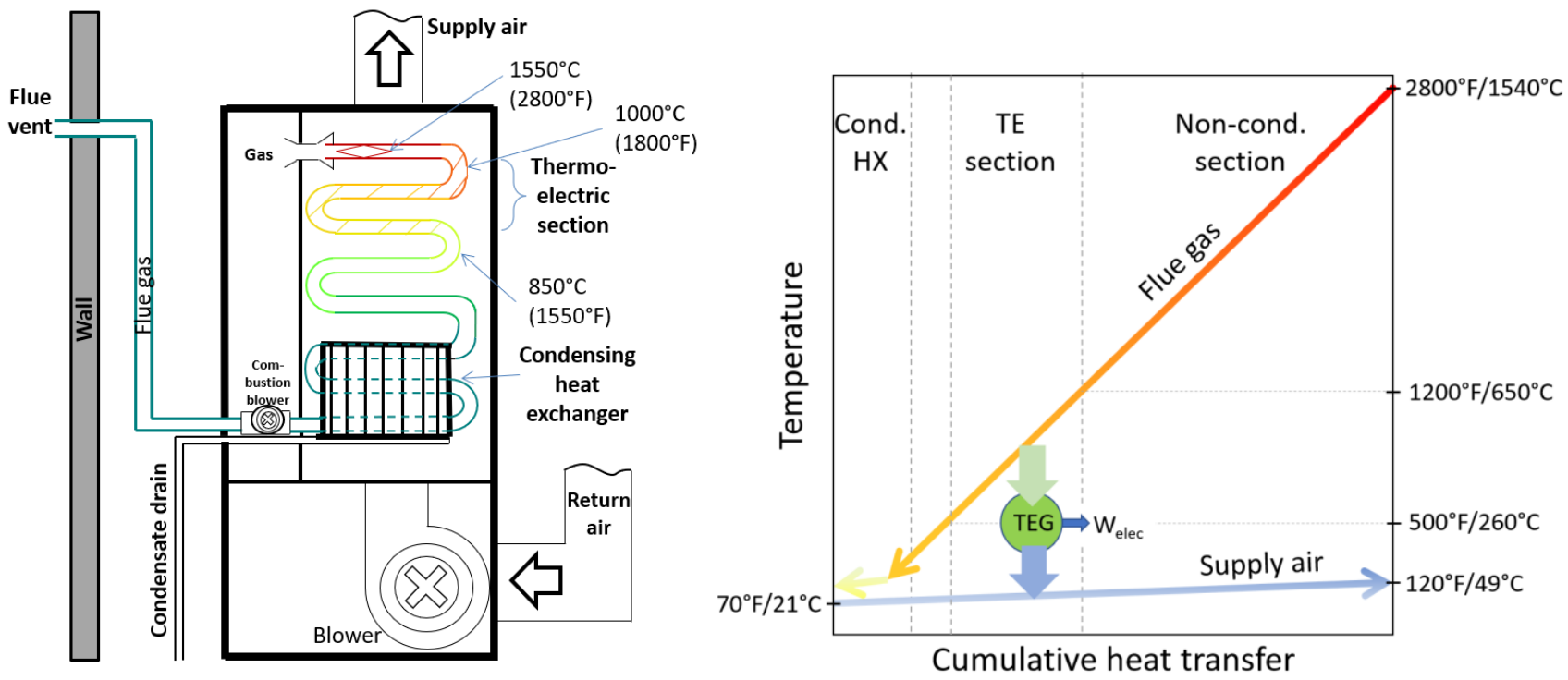

Figure 11: Concept of a thermoelectric self-powered furnace

\subsubsection{Organic Rankine}

Organic Rankine Cycle uses fluids with relatively low boiling temperature and hence it is suitable for application of low temperature heat source. At the heart of the ORC system is the expander, the power extracting device. At power level $\sim 1 \mathrm{~kW}$, piston expanders are the most suitable. Expanders for ORC are not widely available commercially and their off-the-shelf price currently is quite high. Guoquan (2010) reported on the findings of market research of expanders. A commercial off-the-shelf $1 \mathrm{~kW}_{\mathrm{e}}$ expander costs $\$ 10,000$. However, the authors reported that they successfully used an off-the-shelf vane-type air motor as an expander for an ORC. Air motors are mass produced and they cost two orders of magnitude less than the price of the commercially available $1 \mathrm{~kW}_{\mathrm{e}}$ expander. ORCs have simple makeup and could be a good match for a self-powered furnace if (a) a suitable expander is identified and (b) the heat rejection condenser can be made compactly enough. 


\subsubsection{Stirling}

Extensive review of different Stirling engine types and related experimental work was presented in Kai (2016). Kinetic Stirling engines are promising technology; however, they have low power-to-weight ratio. With the heat source at lower temperatures $\left(<\sim 300^{\circ} \mathrm{C}\right)$, they run at low efficiencies and their sizes become large. Although efficiency itself is not a deciding factor in our application, the size is a limiting factor, as the power generating cycle has to fit in a traditional sized furnace. Acoustic Stirling engines are much simpler, quieter and more reliable. These characteristics are attractive to our application. However, acoustic Stirling engine are not produced on a commercial scale. Several prototypes were built and were evaluated experimentally. Thermal efficiencies on the order of $30 \%$ were reported.

\subsubsection{Thermo-magneto-electric (TME) generators}

This is a solid-state heat engine. The technology utilizes a second order magnetic (ferromagnetic paramagnetic) phase transition of magnetocaloric material under thermal gradient inside a magnetic field to generate mechanical energy.

\subsubsection{Magneto-hydro-dynamic (MHD) generators}

These devices utilize the heat of combustion to accelerate ionized gas or (usually liquid-) metal-laden gas through a magnetic field to generate electric current. This type of generator is simple in principal with no moving parts and low maintenance requirements. Between the 1970s and the 1990s, there was a significant interest in this technology as a topping cycle in combined cycle power plants. Significant advancements were made during a DOE multiyear program in the 1980s to develop open-cycle, coalfired, MHD electric power generation. Investment in developing the technology stopped because of the change in national energy research objectives. There has been renewed interest in the MHD technology recently. New research in MHD is led by NETL through the Direct Power Extraction initiative.

With their quietness level and the low maintenance requirements, MHDs are well poised for deployment in self-powered furnaces. However, they are still at a low maturity stage and significant development is needed before they are ready for commercial adoption.

\section{SUMMARY}

The technologies surveyed are summarized in Table 4 . 
Table 4: Key attributes of each generator technology

\begin{tabular}{|c|c|c|c|c|c|c|c|c|c|}
\hline $\begin{array}{l}\text { Config- } \\
\text { uration }\end{array}$ & Technology & $\begin{array}{l}\text { Sub- } \\
\text { category }\end{array}$ & $\begin{array}{l}\text { NOx CO } \\
\text { generator } \\
\text { emissions }\end{array}$ & Noise & $\begin{array}{l}\text { Maintenance } \\
\text { interval }\end{array}$ & $\begin{array}{l}\text { Rapid } \\
\text { cycling }\end{array}$ & $\begin{array}{l}\text { Heat } \\
\text { exchanger } \\
\text { requirements }\end{array}$ & TRL & $\$ / \mathbf{W}$ \\
\hline \multirow{7}{*}{$\begin{array}{l}\text { Topping } \\
\text { cycles }\end{array}$} & \multirow[t]{3}{*}{ ICE } & $\begin{array}{l}\text { 4-stroke } \\
\text { recip. }\end{array}$ & Moderate $^{1}$ & High & $\begin{array}{l}\text { Poor to } \\
\text { acceptable }^{3}\end{array}$ & V. good & Good $^{4}$ & $7-9$ & $\$ \$$ \\
\hline & & $\begin{array}{l}2 \text {-stroke } \\
\text { recip. }\end{array}$ & v. high & High & $\begin{array}{l}\text { Poor to } \\
\text { acceptable }\end{array}$ & V. good & Good $^{4}$ & $7-9$ & $\$$ \\
\hline & & Wankel & High & High & $\begin{array}{l}\text { V. Poor to } \\
\text { poor }\end{array}$ & V. good & Good $^{4}$ & $6-8$ & $\$ \$$ \\
\hline & \multirow[t]{2}{*}{ Fuel Cell } & SOFC & High $^{1}$ & Low & $\begin{array}{l}\text { Poor to } \\
\text { acceptable }\end{array}$ & V. poor & Excellent & $4-6$ & $\$ \$ \$ \$$ \\
\hline & & PEMFC & & Low & & Poor & Moderate & $6-8$ & $\$ \$ \$$ \\
\hline & \multicolumn{2}{|l|}{ MT } & Moderate $^{1}$ & $\begin{array}{l}\text { V. } \\
\text { High }\end{array}$ & Good & Good & $\begin{array}{l}\text { Excellent (all } \\
\text { heat in } \\
\text { exhaust) }\end{array}$ & $6-9$ & $\$ \$$ \\
\hline & \multicolumn{2}{|l|}{ Thermo-PV } & Low & None & Good & Good & V. good & $3-5$ & $\$ \$ \$$ \\
\hline \multirow{5}{*}{$\begin{array}{l}\text { Heat } \\
\text { engines }\end{array}$} & $\mathrm{TE}$ & $\begin{array}{l}\text { BiTe, } \\
\text { SiGe }\end{array}$ & None & None & V. good & Moderate & Good $^{5}$ & $5-8$ & $\$ \$ \$$ \\
\hline & \multicolumn{2}{|l|}{ TME } & None & None & Long & V. Good & Good $^{5}$ & $2-4$ & $\$ \$ \$$ \\
\hline & \multicolumn{2}{|l|}{ MHD } & $\begin{array}{l}\text { High or } \\
\text { None }^{2}\end{array}$ & None & Long & V. Good & Good $^{5}$ & 5 & $\$ \$ \$ \$$ \\
\hline & \multicolumn{2}{|l|}{ Stirling } & None & Low & Poor & Moderate & Poor $^{5}$ & 6 & $\$ \$ \$$ \\
\hline & \multicolumn{2}{|l|}{ ORC } & None & Low & Long & V. Good & Poor $^{5}$ & 8 & $\$ \$ \$$ \\
\hline
\end{tabular}

Table notes:

${ }^{1}$ can be mitigated by feeding the exhaust to the main combustors

${ }^{2}$ when configured as bottoming cycle, it does not produce emissions

${ }^{3} 10-5000 \mathrm{hr}$ low end of range reflects standard; high end reflects engines optimized for long maintenance intervals

${ }^{4} 50 \%$ of heat rejected in exhaust; air cooling is feasible for the remainder

${ }^{5}$ all heat engines must reject their heat to the supply air stream through a heat exchanger. The better requirements are when the heat rejection temperature can be very high.

\section{ACKNOWLEDGEMENTS}

The authors would also like to thank Edgar Lara-Curzio for his helpful discussions regarding fuel cells and Tim Laclair for the review comments.

\section{REFERENCES}

AIE UK 2018. http://www.aieuk.com/

Air-conditioning, Heating and Refrigeration Institute (AHRI). Historical Data. 2017.

http://ahrinet.org/Resources/Statistics/Historical-Data.aspx (accessed December 18, 2017).

Aisin. http://www.aisin.com/product/energy/, http://www.aisin.co.jp/cogene/coremo.html 
Ferrari, C. et al., Overview and Status of Thermophotovoltaic Systems, 68th Conference of the Italian Thermal Machines Engineering Association, Energy Procedia 45 (2014) 160 - 169.

Fry, D. et al., Compact Portable Electric Power Sources, ORNL/TM-13360, Oak Ridge National Laboratory, Oak Ridge, TN, Feb. 1997.

Gaultois MW, Sparks TD, Borg CKH, Seshadri R, Bonificio WD, Clarke DR. "Data-Driven Review of Thermoelectric Materials: Performance and Resource Considerations," Chemistry of Materials. 2013; 25(15): p. 2911-2920, doi:10.1021/cm400893e.

Gentherm Global Power Technologies - Head Office: 16, 7875 - 57 Street S.E., Calgary, AB, Canada T2C 5K7, http://www.genthermglobalpower.com

Guoquan Qiu, Hao Liu, Saffa Riffat, Expanders for micro-CHP systems with organic Rankine cycle, In Applied Thermal Engineering, Volume 31, Issue 16, 2011, Pages 3301-3307, ISSN 1359-4311, https://doi.org/10.1016/j.applthermaleng.2011.06.008.

(http://www.sciencedirect.com/science/article/pii/S1359431111003188)

Honda. http://world.honda.com/power/cogenerator/

Hormaza-Mejia A, Zhao L, Brouwer J. SOFC Micro-CHP System With Thermal Energy Storage in Residential Applications. ASME. International Conference on Fuel Cell Science, Engineering and Technology, ASME 2017 15th International Conference on Fuel Cell Science, Engineering and Technology ():V001T02A001. doi:10.1115/FUELCELL2017-3142.

Kai Wang, Seth R. Sanders, Swapnil Dubey, Fook Hoong Choo, Fei Duan, Stirling cycle engines for recovering low and moderate temperature heat: A review, In Renewable and Sustainable Energy Reviews, Volume 62, 2016, Pages 89-108, ISSN 1364-0321, https://doi.org/10.1016/j.rser.2016.04.031.

Kass, M., Noakes, M., Kaul, B., Edwards, D. et al., "Experimental Evaluation of a 4-cc Glow-Ignition Single-Cylinder Two-Stroke Engine," SAE Technical Paper 2014-01-1673, 2014, doi:10.4271/2014-01-1673.

Lawrence, Chrishelle, and Chip Berry. "U.S. households' heating equipment choices are diverse and vary by climate region." Today in Energy. U.S. Energy Information Administration. April 6, 2017.

Lewis Fraas. "Design of a Portable Fuel Fired Cylindrical TPV Battery Replacement", 9th Annual International Energy Conversion Engineering Conference, International Energy Conversion Engineering Conference (IECEC) (2011) https://doi.org/10.2514/6.2011-5653

LiquidPiston. http://liquidpiston.com/

Littera, D., Nickerson, M., Kopache, A., Machamada, G. et al., LiquidPiston, Inc. "Development of the XMv3 High Efficiency Cycloidal Engine," SAE Technical Paper 2015-32-0719, 2015.

Marlow Industries, Inc., 10451 Vista Park Rd., Dallas, Texas 75238 USA

http://www.marlow.com 
Microturbines and Small Turbomachinery; Oil and Gas Applications; Wind Turbine Technology ():229238. doi:10.1115/GT2010-22007.

Nelson R.E., Grid-independent residential power systems, AIP Conference Proceedings 358, 221 (1996).

Oiu K, Haden A., Implementation of a TPV integrated boiler for micro-CHP in residential buildings, Applied Energy 134 (2014) 143-149

Scarpete D, Badea N. Stirling Engine: An Emerging Prime Mover for Micro-CHP Systems. ASME. Engineering Systems Design and Analysis, ASME 2010 10th Biennial Conference on Engineering Systems Design and Analysis, Volume 1 ():299-305. doi:10.1115/ESDA201025212 .

Szybist J., Thomas J. Kaul B., Performance of a Half-Heusler Thermoelectric Generator for Automotive Application, Draft SAE paper, expected publication April, 2018.

Zachary Taie, West, B., Szybist, J. Edwards, K., Thomas, J., Huff, s., Vishwanathanc, G., Hagen, C., Detailed thermodynamic investigation of an ICE driven, natural gas fueled, $1 \mathrm{kWe}$ micro-CHP generator, Submitted to Applied Energy Journal.

T.J. Theiss, J.C. Conklin, J.F. Thomas, and T.R. Armstrong, Comparison of Prime Movers Suitable for USMC Expeditionary Power Sources, ORNL/TM-2000/116, report for USMC Warfighting Laboratory, Quantico, VA, Oak Ridge National Laboratory, Oak Ridge, TN, March, 2000.

Twaha S, Zhu J, Yan Y, Li B. "A comprehensive review of thermoelectric technology: Materials, applications, modelling and performance improvement," Renewable and Sustainable Energy Reviews. 2016 November; 65: p. 698-726, doi:10.1016/j.rser.2016.07.034.

U.S. Department of Energy. Technical Support Document: Energy Efficiency Program for Consumer Products and Commercial and Industrial Equipment: Residential Furnaces. Washington, DC: Office of Energy Efficiency and Renewable Energy, 2015.

U.S. Energy Information Administration (EIA). 2015 RECS Survey Data. November 2, 2017. https://www.eia.gov/consumption/residential/data/2015/ (accessed December 18, 2017).

Visser WJ, Shakariyants SA, Oostveen MM. Development of a 3kW Micro Turbine for CHP Applications. ASME. Turbo Expo: Power for Land, Sea, and Air, Volume 5: Industrial and Cogeneration;

Brian West, Keith Knoll, Wendy Clark, Ronald Graves, John Orban, Steve Przesmitzki, Timothy Theiss, Effects of Intermediate Ethanol Blends on Legacy Vehicles and Small Non-Road Engines, Report 1, Oak Ridge National Laboratory and National Renewable Energy Laboratory, NREL/TP-54043543 or ORNL/TM-2008/117, October 2008.

Thermal Electronics Corp. 5 Furbacher Lane, Unit 4, Aurora, Ontario L4G 6W2 http://thermoelectricgenerator.com\ 